\title{
Socio-Cultural Competence in Teaching Foreign Languages
}

\author{
Igor Olegovich Guryanov ${ }^{1}$, Alina Eduardovna Rakhimova ${ }^{1} \&$ Marisol C. Guzman $^{2}$ \\ ${ }^{1}$ Kazan Federal University, Russia \\ ${ }^{2}$ Gabriel René Moreno Autonomous University \\ Correspondence: Igor Olegovich Guryanov, Kazan Federal University, Russia. E-mail: igor.goor@gmail.com
}

Received: July 17, 2019

doi:10.5430/ijhe.v8n7p116

Accepted: October 10, $2019 \quad$ Online Published: October 28, 2019

URL: https://doi.org/10.5430/ijhe.v8n7p116

\begin{abstract}
This article addresses the problem of integrating socio-cultural components into teaching and upbringing through foreign languages. The aim of teaching a foreign language means not only acquiring communication skill but also forming cultural and linguistic personality. The main aim of any communication is to be understood by interlocutor. The effectiveness of this process is directly dependent on the reached level of mutual understanding between communicants. To achieve this aim partners should have the willingness and capacity to form dialogue of cultures which presupposes the existence of a socio-cultural competence. Sociocultural competence includes knowledge about values, beliefs, behavior patterns, customs, traditions, language and cultural achievements peculiar to society. This competence occurs in the framework of socio-cultural education and training, i.e. in the process of personalizing the culture and national traditions of the studied language country.
\end{abstract}

Keywords: sociocultural competence, education, foreign language, dialogue of cultures

\section{Introduction}

Today's world is composed of many different countries, each of which has its own culture and language due to its own history, and this variety and variety sometimes makes it difficult for people to live together. Language is merely a means of communication but it also expresses the personality of the universe, their imagination and the method of transferring knowledge. Also, the transfer of a concept from culture to culture will always require the challenge of change from an intellectual system to another, and these inseparable intellectual systems can be the source of mutual misunderstanding and even humiliation and disregard for individuals and relatives (Ali Al Briki, M. H., \& Rahman Khan, M. F. (2019).. Nevertheless, language lessons should encourage students to be free from prejudice of foreign cultures and make them capable of intercultural communication.

The advent of a phenomenon called "globalization" and its impact on all social, economic, cultural and ethical dimensions, the need for communication between nations and among people within each country, mutual understanding and tolerance of each other, day by day increases. Hence, Encouraging people to learn languages that form part of their heritage or languages that allow interrelationship on the international scene has continued since the start of the new era in the lives of most people in the country. Today, acquiring skills in one or more foreign languages by citizens from different countries is a prerequisite for the comprehensive participation in the international community and the use of its opportunities (Ali Al Briki, M. H., \& Rahman Khan, M. F. (2019).. This is to an extent that, for example, it is recommended in Europe that at least two foreign languages related to other European countries be acquired by the younger generation of the continent in order to create a better understanding and communication between the people of these countries (Leclercq, 2003; Ebrahim Abadi \& Namdar, 2016; Boroomand et al., 2016).

The European Parliament proclaimed 2001 as the European Year of Languages, and aimed to raise awareness of the cultural and linguistic diversity and richness of the region and to learn other languages as the key to the development of individual relations and Recommend a job with others Language cannot be taught and learned without native speakers' society. Acquired information about natural conditions and lives of other culture representatives and political, economic and cultural development is of great importance in the teaching process (Ali Al Briki, M. H., \& Rahman Khan, M. F. (2019).. Discussions about cultural peculiarities of a studied language country, as well as acquaintance with routine problems, can arise interest in unknown culture and language and create a deeper understanding of them. In the modern system of education intercultural communication, it is widely integrated in the 
learning process as one of the leading humanitarian disciplines. (Solnyshkina, et al., 2016; Ali Al Briki \& Rahman Khan, 2019; Mazana et al., 2019).

\section{Materials and Methods}

The effectiveness of the model of intercultural communicative competence through project technology has been tested in the course of research practice. The aim of the experimental work was that, the development of creative, analytical and predictive capacity provides in parallel with the development of intercultural communicative competence. It tells the estimation of the efficiency of using computer technologies and multimedia for the organization of independent educational activity of students at language high school, as well as the educational process management mechanism will be the method of project work as an educational process is based on the conceptual provisions of the cognitive and lingvocultural methodology implemented within the framework of competent and learner-centered approaches. The base of the experimental work conducted at Kazakh Ablai Khan University of International Relations and World Languages, specialty - «Journalism». Correspondingly, at the end of the study students of this specialty will form intercultural and communicative competence. Intercultural communicative competence involves the ability of students to produce their own texts in oral and written form in accordance with a given communication task. According to the curriculum on this discipline 60 hours of practical classes and 60 hours of independent work of students (IWS) were given, which includes the students' independent work and independent work under the guidance of a teacher. The leading form of activity was teamwork. Within the household, educational and cognitive, social and cultural spheres students' team work was organized mainly for implementation of projects: Student's Time Managing, Seven Global Challenges, Mass Media in Kazakhstan and abroad, Life in Colour and others. Discipline consists of four modules, each of which registers an independent activity for students during classroom and extracurricular work. The formative phase of experimental work has been linked to experimental verification in e-learning environment as Moodle. There were 2-year-students (26 students 13 students in the experimental and 13 students in the control INTERNATIONAL JOURNAL OF ENVIRONMENTAL \& SCIENCE EDUCATION 7893 groups), in the specialty "Journalism" in forming experiment. In the second year of training and the level of mastery of foreign language according to "European standards of language competence" and the national education system corresponds to B2 - level of basic standard. The teacher himself/herself offered students the theme according to the curriculum called "Mass Media in Kazakhstan and abroad". In preparation we had to observe, survey, interview; to determine the type of the experiment; to ensure equal conditions for students of experimental and control groups; to conduct pre-experimental diagnostics of formation of intercultural communicative competence. The period of the project held 2 weeks. Students divided into teams of 4-5 people. All students of the project team had clearly formulated goals, however, they determined objectives themselves and the hypothesis of the project. Students jointly worked through the algorithm to achieve goals, assigned roles in the team, carried the mutual responsibility for the results of joint activity. Students elaborated creative tasks on the project with the use of informative and communicative technologies through the Moodle learning management system. Considering the sequence of execution of the project in the unfolded state: Step 1: searching and studying the problem. Students discuss the topic of the project, taking into account their personal needs and opportunities, independently determine the problem and formulate the goal. At this stage, the project work of the teacher's task is to provide students with tutorial. Step 2: defining the project goals. Students formulate goal of the project their own and the teacher helps. Step 3: preparation of the project implementation plan. Students make their own plan for the implementation of the project. The teacher advises the plan drafting, consults students, stimulates and monitors. As the project is limited in time, each student should determine their own pace of project implementation activity. Step 4: implementation of the project. At this stage, the activity of students about the implementation of the project objectives on a definite plan accomplishes. Step 5: project defense. Students demonstrate work by using information and communication technologies in remote Moodle program. All teams evaluate each other on the previously specified pattern criteria and explain the reason for this assessment, beginning with the words: "We liked ..." "We do not like ..." and "We recommend ...". During this process the teacher is watching remotely, controlling the whole process online at any time for everyone. Thus, all the groups evaluate each other online. The next lesson students ask questions each other, where they are trying to find out the details of the implementation of project activity. A teacher also comments, and concludes. At this stage of this activity such skills as self-esteem, self-control, reflection the ability to analyze and justify his or her own point of view are formed. Focusing on the creation of the project as a personal educational product makes the process of mastering the knowledge of the subject personally meaningful and personally motivated for a learner himself or herself. 


\section{Results and Discussion}

The phenomenon of globalization also has an impact on education, and one of its dimensions is the shift of professor, student, and knowledge around the world. Graduates of schools and universities are not confined to the labor market in the country, and if they achieve the required expertise and compete in the region or international scene, they can be trained wherever they wish. Undoubtedly, Knowing and mastering a foreign language is one of the preconditions for this movement and mobility to seek education and employment in other parts of the world, and education should accept the responsibility of teaching foreign language as a means of scientific promotion as well as means Employment and education of the citizens of the country and, in keeping with the quality of this training and raising it at the level of regional and global standards, will provide conditions for the presence of high-quality forces of society. Long sentence - rewrite for clarity - shorten Hence, it is no coincidence that teaching foreign languages has increased with the growing need of countries for global communication and has accelerated its teaching throughout the secondary and secondary schools (and in many countries to the earliest). Undoubtedly, paying attention to foreign languages and teaching it is not limited to the generalization of language proficiency throughout pre-university education, and the emphasis on different aspects of language learning from writing, reading and translation skills to verbal ability to communicate with other countries has fluctuated (Safonova, 1999; Nebessayeva et al., 2018; Martínez-Alcalá et al, 2018).

It should be noted that the further cultures are distant from each other, the greater is the probability of intercultural misunderstandings .

Thus, the socio-cultural competence covers the following aspects:

- formation and achievement of this competence in foreign culture;

- reflection of one's own culture and ability to talk about it in a foreign language;

- achievement of intercultural understanding leading to tolerance and mutual respect (Byram, et al., 2009).

- socio-cultural competence is multidimensional. obligatory components are linguistic-regional, regional, sociolinguistic and general cultural. This opens ample opportunities for professional and humanity training of young participants in the dialogue of cultures;

- socio-cultural competence makes it possible to pattern student's behavior in an authentic language environment, allowing to predict and thereby avoid possible difficulties that arise in another sociocultural environment;

- the basis for socio-cultural competence is cultural studies, which gives a true picture of the country's socio-cultural portrait, including historical and cultural knowledge, values and way of life of the peoples of the country;

- a major role in the formation of socio-cultural outlook plays a social and cultural background of students' native environment (Dulganova, 2004).

The goal of sociocultural learning is, therefore, not only the knowledge and knowledge of another culture, but also the ability to portray critically its own culture (Vartanov, 2003).

In the classroom of a foreign language, it is not just a matter of communicating language knowledge. Many Western curricula on foreign language contain the requirement that trainees should master socio-cultural competence (Tarasova \& Kormiltseva, 2016).

Let us consider the criteria of socio-cultural competence:

- Important information about your own country. Foreign culture can be studied and understood only through the prism of domestic culture. Socio-cultural prerequisites are not always recognized by the students, they are perceived as a reality, therefore, there is no corresponding knowledge in their own culture;

- To establish efficient communication with a native speaker, the trainees need knowledge in the areas of geography, politics, social sphere, culture and science.

Russian teachers distinguish the following criteria for assessing regional geography:

- Validity. Requires correctness of information, authenticity of texts and situational accuracy;

- Presentation. Important typical moments are essential, without which it is impossible to understand the country of the language being studied, at the same time it is necessary to inculcate awareness of internal diversity and differentiation;

- Realistic depicturing. A realistic picture of culture should be presented, including conflicts and problems arising in the given society; 
- Audience correspondence. The content should correspond to the age, should be interesting and understandable. It should also provide an opportunity for comparison, evaluation, development of a common cultural features (Khasanova e al. 2016).

\section{Summary}

By analyzing need to earlier state data analysis choice, form and justification for this research various approaches to the definition of socio-cultural competence, they confirm thesis of simultaneous acquiring foreign languages and its' culture history and modern life by the students. Therefore, they may state that sociocultural aspect should become permanent, an integral part of the process of education and upbringing. This allows to identify the main objectives of the formation of socio-cultural competence:

- The goal of education is humanizing education, training students in the spirit of a dialogue of cultures, fostering mutual understanding and tolerance towards a foreign culture, the ability to treat it with respect, but critically; the manifestation of interest in contact with a different culture, the perception of one's own values and cultural values of the countries of the studied language;

- The general educational goal promotes awareness of socio-cultural information in the process of interaction with elements of a different culture, understanding and interpretation of cultural interrelationships;

- The developing goal makes it possible to use sociocultural background for understanding and interpreting socio-cultural elements, for a reference point in the value categories of one's own and other societies, to develop the willingness to make choices, make independent decisions, and formulate one's own point of view.

- The practical goal helps to communicate tolerantly in various life situations in relation to the partner in communication, to use, with direct contact, adequate speech resources, to use knowledge of the sociocultural background in professional activity (Safina \& Amurskaja, 2017).

According to the theory of sociocultural learning, the mastery of a foreign language means perception of individual and collective mentality, culture of another people and assumes acquaintance with the views, assessments and experiences of another cultural community. As a form of education innovation, the introduction of the new course needed to be managed effectively at the micro-educational level in order to achieve such aims (Weinert, 2001).

\section{Conclusion}

The relationship between language and culture has long been of interest to philosophers, sociologists, and linguists. Concerns about the origin of language and the relation between language and thought, thought and culture and language and culture are interesting for those interested in various fields of human sciences. In recent years, as a result of the expansion of the focus on teaching in theoretical and practical aspects, this topic has also been replaced by the foreign language teaching, and the importance of training these two in parallel.

The emphasis on foreign language teaching has been growing in recent years, and in the same way, many schools are trying to provide the best method for teaching. However, still, learners who have learned in foreign language schools or institutions cannot communicate effectively in the real context. Many reasons for this have been discussed so far, such as the lack of effective teachers and modern literacy resources. But-One of the factors that can help foreigners learn foreign language learners outside the context of the target language community is to familiarize teachers with their culture and their relationship with language.

In today's world, where its components are culturally interlinked, cultural understanding is the main component of communication or non-relevance. This means that language learning goals can no longer be considered only in the language process, but should lead to language learning in line with its intercultural communication capability. Therefore, foreign language instructors are required to use and enhance their intercultural competence among their students.

The condition of the new concept of sociocultural learning is the introduction of additions to the content of language education. Filling the content of the language course with a sociocultural component can serve as a means of motivating students' speech activity and learning the development of the sociocultural educational needs of the trainees.

\section{Acknowledgements}

The work is performed according to the Russian Government Program of Competitive Growth of Kazan Federal University. 


\section{References}

Ali Al Briki, M. H. \& Rahman Khan, M. F. (2019). Managing Students \& Employees Through College Information Management System (Cims) - A Case Study: Shinas College Of Technology (Shct), OMAN. Humanities \& Social Sciences Reviews, 6(2), 90-99. Retrieved from http://giapjournals.com/index.php/hssr/article/view/hssr.2018.6211

Boroomand, Z., Momeni, M. \& Torkashvand, M. H. (2016). Evaluating the Possibility of Establishing Knowledge Management in State Welfare Organization of Iran. UCT Journal of Management and Accounting Studies, 4(2), $7-15$.

Byram, M., Nichols, A. \& Stevens, D. (Eds.) (2009). Developing Intercultural Competence in Practice. Great Britain: Cromwell Press.

Dulganova, V. N. (2004). Role of Pragmatics in Intercultural Communication. Russian-German forum. Ulan-Ude: BGU-Verlag, 82-83.

Ebrahim Abadi, M. \& Namdar, Sh. (2016). Comparison between the legal nature of commercial factoring and similar legal institutions. UCT Journal of Social Sciences and Humanities Research, 4(2), 10-15.

Khasanova Oxana, V. \& Karimova Anna, A. (2016). Esl Teacher Professional Self-development within Lifelong Educational Environment". IFTE 2016 - 2nd International Forum on Teacher Education, 12, 60-66.

Leclercq, J.- M. (2003). Facets of interculturality in education. Responses to Violence in Everyday Life in a Democratic society. Strasbourg: Council of Europe Publishing.

Martínez-Alcalá, C. I., Ramírez-Salvador, J. A., Rosales-Lagarde, A. \& Jiménez-Rodríguez, B. (2018). Assistance and Support of Primary Caregivers through an eService Platform, Journal of Information Systems Engineering \& Management, 3(1), 09.

Mazana, M. Y., Montero, C. S. \& Casmir, R. O. (2019). Investigating Students' Attitude towards Learning Mathematics. International Electronic Journal of Mathematics Education, 14(1), $207-231$. https://doi.org/10.29333/iejme/3997

Nebessayeva, Z., Bekbolatova, K., Mussakulov, K., Zhanbirshiyev, S. \& Tulepov, L. (2018). Promotion of entrepreneurship development by art and design by pedagogy, Opción, 34(85-2), 729-751.

Safina, R., Amurskaja, O. (2017). The technology of development of intercultural competence at Russian and foreign universities. European Proceedings of Social and Behavioral Sciences, 727-735.

Safonova, V. V. (1999). Socio-Cultural Approach to Teaching Foreign Languages. Moscow: Higher School, Amscort International.

Solnyshkina, M. I., Solovova, N., Harkova, E. V. \& Kiselnikov, A. S. (2016). Language Assessment course: Structure, Delivery and Learning Outcomes. International Journal of Environmental \& Science Education, 11(6), 1223- 1229.

Tarasova, F. Kh. \& Kormiltseva, A. L. (2016). The Gender Marked Phraseological Units Coding Female Intelligence in the Russian and English Languages IEJME-Mathematics Education - IEJME Article, November, 179 , 2015-2024.

Vartanov, A. V. (2003). From teaching foreign languages to teaching foreign languages and cultures. Foreign Language at School, 2, 21-25.

Weinert, F. E. (2001). Concept of competence: A conceptual clarification. Defining and Selecting key Competencies. Seattle: Hogrefe, 45-66. 